\title{
GAMBARAN KECEMASAN DAN DEPRESI WANITA DENGAN KANKER PAYUDARA
}

\author{
Michelle Tania $^{1}$, Naomi Soetikno ${ }^{2}$, Meiske Yunithree Suparman ${ }^{3}$ \\ ${ }^{1}$ Program Studi Magister Fakultas Psikologi, Universitas Tarumanagara Jakrta \\ Email: Michelletania3112@gmail.com, \\ ${ }^{2}$ Fakultas Psikologi, Universitas Tarumanagara Jakrta \\ Email: Naomis@fpsi.untar.ac.id \\ ${ }^{3}$ Fakultas Psikologi, Universitas Tarumanagara Jakrta \\ Email: Meiskey@fpsi.untar.ac.id
}

Masuk :14-04-2019, revisi: 10-09-2019, diterima untuk diterbitkan : 11-09-2019

\begin{abstract}
ABSTRAK
Kanker merupakan penyakit kronis yang banyak diderita oleh individu di seluruh dunia. Hal ini menjadikan kanker dianggap sebagai penyakit yang tidak bisa disembuhkan dan akan menyebabkan kematian bagi penderitanya. Salah satu jenis kanker yang paling banyak diderita oleh wanita yaitu kanker payudara. Kanker payudara merupakan keganasan yang berasal dari kelenjar payudara. Diagnosis kanker payudara akan berdampak kepada keadaan psikologis individu, termasuk kecemasan dan depresi. Penelitian ini bertujuan untuk menggambarkan kecemasan dan depresi pada pasien wanita dengan kanker payudara. Desain penelitian ini adalah penelitian deskriptif dengan menggunakan alat ukur Hospital Anxiety and Depression Scale (HADS). Pada penelitian ini, pengambilan sampling dilakukan dengan menggunakan teknik accidental sampling. Partisipan penelitian ini berjumlah 34 orang dengan rata-rata usia 53 tahun dan rata-rata partisipan sudah didiagnosis kanker payudara selama 2 tahun. Hasil dari penelitian menunjukkan bahwa partisipan memiliki tingkat kecemasan hingga mild yaitu sebanyak 7 (20,6\%) orang dan $27(79,4 \%)$ lainnya memiliki tingkat kecemasan yang normal. Selain itu, partisipan memiliki tingkat depresi hingga mild yaitu sebanyak $3(8,8 \%)$ orang dan $31(91,2 \%)$ partisipan lainnya memiliki tingkat depresi yang normal. Selain melihat kecemasan dan depresi pada wanita dengan kanker payudara, penelitian ini juga melihat adanya faktor-faktor lain yang dapat mempengaruhi tingkat kecemasan dan depresi pada wanita dengan kanker payudara, yaitu faktor religiusitas dan faktor dukungan sosial.
\end{abstract}

Kata Kunci: kecemasan, depresi, kanker payudara

\begin{abstract}
Cancer is a chronic disease affection many individuals throughout the world, leading us to consider it an incurable disease and will certainly cause death for those afflicted with it. One of the most common types of cancer in women is breast cancer. Breast cancer is a malignancy originating from the mammary gland. The diagnosis of breast cancer will affect an individual's psychological state in the form of anxiety and depression. This study aims to describe anxiety and depression in female patients with breast cancer. The design of this study is a descriptive study using the Hospital Anxiety and Depression Scale (HADS) measurement tool. In this study, sampling was conducted using accidental sampling technique. Participants in this study were 34 people with mean age of 53 years and on average, participants had been diagnosed with breast cancer for 2 years. The result of the study showed that participants who had up to mild anxiety levels were as many as 7 (20.6\%) people, with 27 (79.4\%) others had normal anxiety levels. In addition, as many as 3 participants had up to mild level of depression (8.8\%) and 31 $(91.2 \%)$ other participants had normal depression level. In addition to looking at anxiety and depression in women with breast cancer, this study also looked at other factors that could affect the level of anxiety and depression in women with breast cancer, namely religiosity and social support factors.
\end{abstract}

Keywords: anxiety, depression, breast cancer

\section{PENDAHULUAN}

\section{Latar belakang}

Kanker merupakan penyakit kronis yang banyak diderita oleh individu di seluruh dunia. Masyarakat di banyak bangsa seringkali menganggap bahwa kanker merupakan penyakit yang tidak bisa disembuhkan, penyakit yang dapat menyebabkan kematian dan lebih sering dialami 
oleh individu yang sudah berusia lanjut. World Health Organization (WHO, 2018), mengatakan bahwa Penderita kanker mencapai 18,1 juta di tahun 2018. Selain itu, WHO (2018) juga mengatakan bahwa jumlah penderita kanker yang meninggal di tahun 2018 mencapai 9,6 juta. Hal ini menyebabkan kanker menjadi salah satu dari empat penyebab kematian tertinggi dan tak bisa ditangani di seluruh dunia (Cable News Network, 2018).

Di Indonesia, prevelensi penderita penyakit kanker mengalami peningkatan dalam lima tahun terakhir. Pada tahun 2013, penderita kanker di indonesia mencapai 1,4 per 100 penduduk dan pada tahun 2018 meningkat menjadi 1,79 per 1000 penduduk (Berita Satu, 2018). Hal ini didukung oleh Global Burden Cancer (GLOBOCAN) (dalam Berita Satu, 2018), yang mengatakan bahwa pada tahun 2018 penderita kanker Di Indonesia mencapai 136,2 per 100.000 penduduk. Angka tersebut membuat Indonesia berada di urutan kedelapan dengan kasus kanker terbanyak di Asia Tenggara. Di Indonesia kanker juga merupakan penyebab kematian nomor tujuh setelah stroke, TB, hipertensi, cedera perinatal, dan diabetes melitus dengan prevalensi 1,4 per 1.000 penduduk (Widiyono, Setiyarini \& Effendy, 2017).

Kanker merupakan pertumbuhan yang tidak normal dari sel-sel jaringan tubuh yang berubah menjadi ganas (Kemkes, 2016). Selain itu, menurut American Cancer Society (2019), kanker merupakan sekumpulan penyakit yang dikarakteristikan dengan adanya pertumbuhan yang tidak terkontrol dan adanya penyebaran sel yang bersifat abnormal. Menurut WHO (2018), pada pria, kanker yang pada umumnya diderita adalah kanker paru-paru, prostat, usus, perut, dan hati. Sedangkan pada wanita, kanker yang pada umumnya diderita adalah kanker payudara, colorectal, paru-paru, serviks, dan kanker tiroid. Selain itu, WHO (2018), juga mengatakan bahwa kanker paru-paru, kanker payudara pada wanita, dan kanker usus merupakan jenis kanker yang menjadi penyebab kematian terbanyak di seluruh dunia.

Prevelensi kanker pada umumnya lebih tinggi pada wanita yaitu sebesar 5,7 per 1.000 penduduk. Sedangkan pada pria prevalensi penderita kanker sebesar 2,9 per 1.000 penduduk (Widiyono, Setiyarini \& Effendy, 2017). Pada wanita, kanker paling umum diderita adalah kanker payudara yaitu mencapai 1,67 juta kasus di tahun 2012 (Kemkes, 2016). Pada tahun 2018, penderita kanker payudara meningkat menjadi 2,09 juta kasus (WHO, 2018). Hal ini didukung oleh data yang ditunjukkan GLOBOCAN (Dalam WHO, 2018), bahwa kanker payudara merupakan kanker yang paling banyak diderita oleh wanita yaitu sebanyak $24,2 \%$. Angka ini menyebabkan kanker payudara menjadi penyebab kematian kelima di seluruh dunia yaitu mencapai 627.000 atau sekitar 6,6\% (WHO, 2018).

Di Indonesia, jenis kanker yang paling banyak di derita oleh wanita adalah kanker Payudara dengan jumlah penderita mencapai 42,1 per 100.000 penduduk dan kanker Serviks yaitu 23,4 per 100.000 penduduk di tahun 2018 (dalam Berita Satu, 2018). Di Indonesia, kanker payudara juga menjadi penyebab kematian tertinggi pada wanita yaitu mencapai 17 per 100.000 penduduk di tahun 2018 (dalam Berita Satu, 2018). Pada umumnya, wanita yang menderita kanker payudara paling tinggi berusia sekitar 25 - 54 tahun. Hal ini dikarenakan adanya faktor perilaku dan pola makan yang tidak sehat (Kemkes, 2013).

Kanker payudara merupakan keganasan yang berasal dari sel kelenjar, saluran kelenjar, dan jaringan penunjunag payudara (Kemkes, 2009). Kanker payudara dapat disebabkan oleh beberapa faktor yaitu (a) usia; (b) Faktor reproduksi; (c) Sejarah keluarga yang juga menderita kanker payudara; (d) predisposisi genetik; dan (e) faktor lingkungan (Shah, Rosso, \& Nathanson, 2014). Jafari, Gourdazian, dan Nesami (2018), mengatakan bahwa kanker payudara merupakan 
salah satu jenis kanker pada wanita yang memiliki dampak besar terhadap gangguan mental dan emosional dibandingkan dengan jenis kanker lainnya.

Beberapa penelitian menunjukkan bahwa diagnosis kanker payudara memiliki dampak yang negatif terhadap hubungan afeksi, harapan hidup, rencana jangka panjang, produktifitas, dan sosial (Giacomo, et al., 2016). Selain itu juga akan berdampak kepada psikologis dari individu, seperti depresi, kecemasan, kemarahan, mood yang buruk, menarik diri dari sosial, isolasi, dan agresifitas (Giacomo, et al., 2016). Hal ini akan memberi dampak yang cukup besar bagi individu, keluarga, lingkungan sosial, dan lingkungan kerja (Giacomo, et al., 2016).

Callys-Tagoe, et al (2017) juga mengungkapkan Individu yang didiagnosis kanker payudara akan mengalami beberapa gangguan psikologis, termasuk kecemasan dan depresi. Penelitian juga menunjukkan bahwa individu yang menderita kanker payudara lebih beresiko mengalami kecemasan yang parah, depresi, dan gangguan mood (Srlvastava, et al, 2016). Individu yang menderita kanker payudara pada umumnya akan mengalami kecemasan dan depresi pada setiap tahap, dimulai dari pradiagnosis hingga fase terminal (Srlvastava, et al, 2016). Hal ini dikarenakan diagnosis dan penanganan kanker payudara dapat menjadi suatu keadaan yang stressful bagi penderitanya (Srlvastava, et al., 2016). Hal ini didukung oleh hasil penelitian yang menemukan bahwa diagnosis dari kanker payudara diasosiasikan dengan meningkatnya tingkat emosi negatif dan tekanan secara psikologis, terutama simtom-simtom kecemasan dan depresi (Compas \& Luecken, 2002). Selain itu, Badger, et al. (2007) juga mengungkapkan bahwa depresi dan kecemasan sangat berkorelasi dengan individu wanita yang memiliki kanker payudara dan banyak wanita mengalami simtom dari kedua tipe tersebut.

Menurut American Psychiatric Association (APA) (2013), Kecemasan merupakan antisipasi terhadap bahaya yang akan datang di kemudian hari, kecemasan juga seringkali diasosiasikan dengan otot tegang, kewaspadaan dalam mempersiapkan bahaya yang akan datang, dan berhatihati atau perilaku menghindar. Kecemasan pada individu yang memiliki kanker payudara disebabkan oleh ketakutan akan kanker yang semakin menyebar dan penanganan yang diberikan (Baqutayan, 2012). Depresi merupakan gangguan mood yang disertai dengan simtom-simtom emosi, motivasi, perilaku, fisik, dan kognitif (Davey, 2008).

Depresi pada individu yang dikarenakan ketakutan individu akan diagnosis kanker, metabolisme/ endokrin dan gejala emosional yang disebabkan oleh penanganan, ketakutan kambuh kembali, dan adanya dampak pada pekerjaan atau keuangan (Bardwell \& Fiorentino, 2012). Penderita kanker payudara yang mengalami kecemasan dan depresi akan menyebabkan individu menduga hasil yang buruk, merasa bingung mengenai masa depan, kekhawatiran akan kambuh, dan memiliki permasalahan pada konsekuensi dari penanganan yang diberikan (Aly, Eilateef, \& Mohamed, 2017).

Penderita kanker payudara yang mengalami kecemasan akan menyebabkan kelelahan, hasil penanganan yang buruk, berdampak pada kualitas hidup, dan mempengatuhi sistem imun dari penderita kanker payudara (Guan, et. al, 2017). Sedangkan, penderita kanker yang mengalami depresi akan berdampak terhadap keparahan dari kanker, tipe penanganan yang diberikan, rasa sakit, usia, aktifitas fisik, pola makan, simtom atau status menopause, simtom atau fungsi secara fisik, fungsi secara sosial, pesimis, self-esteem, mengekspresikan emosi negatif secara berlebihan, riwayat kejiwaan, dan insomnia (Bardwell \& Fiorentino, 2012). 


\section{Rumusan Masalah}

Rumusan masalah dalam penelitian ini adalah bagaimana gambaran kecemasan dan depresi pada wanita dengan kanker payudara?

\section{METODE PENELITIAN}

\section{Partisipan dan prosedur penelitian}

Penelitian ini dilakukan pada wanita dengan kanker payudara di beberapa rumah sakit yang ada di Bandung pada bulan Maret 2019. Pengambilan sample pada penelitian ini menggunakan accidental sampling. Jumlah partisipan pada penelitian ini adalah wanita dengan kanker payudara yang sudah didiagnosis oleh dokter yaitu sebanyak 34 orang.

\section{Instrumen penelitian}

Variabel dalam penelitian ini adalah kecemasan dan depresi yang diukur dengan menggunakan Hospital Anxiety and Depression Scale (HADS). HADS merupakan alat ukur yang dikembangkan oleh Zigmond dan Snaith. HADS digunakan untuk melihat kecemasan dan depresi secara klinis untuk pasien yang berada di klinik medis umum. Skala ini juga dapat menunjukkan tingkat keparahan dari gangguan mood. HADS terdiri atas 2 dimensi yaitu dimensi kecemasan dan depresi yang terdiri atas 14 butir dan menggunakan skala likert 0-3. Alat ukur ini dapat digunakan dengan rentang usia 16-65 tahun dan dapat digunakan untuk individu yang memiliki keluhan dan penyakit yang beragam (Zigmond \& Snaith, 1983).

Berdasarkan penlitian yang dilakukan oleh Liu, et al (2017) menunjukkan reliabilitas alat ukur HADS yang baik. Pada dimensi kecemasan, reliabilitasnya sebesar $\alpha=0,8$ dan dimensi depresi sebesar $\alpha=0,83$. Interpretasi score hasil HADS dibagi menjadi empat kategori, yaitu (a) 0-7 berarti normal; (b) 8-10 berarti mild; (c) 11-15 berarti moderate; dan (d) $\geq 16$ berarti severe.

Berdasarkan hasil uji normalitas dengan menggunakan Kolmogorov-Smirnov (Tabel 1), diketahui bahwa dimensi kecemasan memiliki nilai $\mathrm{Z}=0,17, \mathrm{p}<0,05$. Hal ini berarti data dimensi kecemasan tidak terditribusi normal. Pada dimensi depresi, diketahui bahwa nilai $\mathrm{Z}=$ $0,133, \mathrm{p}>0,05$ yang berarti data terdistribusi normal.

Tabel 1. Uji Normalitas HADS

\begin{tabular}{llll} 
& & Tot_Kec & Tot_Dep \\
\hline N & & 34 & 34 \\
Normal Parameters & & 3,9118 \\
& Mean & 4,8235 & 2,28788 \\
Most Extreme Differences & Std. Deviation & 3,31636 &, 133 \\
& Absolute &, 170 &, 104 \\
Test Statistic & Positive &, 170 &,- 133 \\
Asymp. Sig. (2-tailed) & Negative &,- 168 &, 133 \\
\hline a. Test distribution is Normal. & &, 170 &, $134^{\text {c }}$ \\
b. Calculated from data. & &, $014^{\text {c }}$ & \\
c. Lilliefors Significance Correction. & & &
\end{tabular}

\section{HASIL DAN PEMBAHASAN}

Partisipan yang berpartisipasi dalam penelitian ini berjumlah 34 orang pasien wanita yang sudah didiagnosis kanker payudara dan didapatkan rata-rata usia 53 tahun serta rata-rata lamanya terdiganosis kanker payudara adalah 2 tahun. Sedangkan rata-rata stadium yang diderita oleh partisipan adalah stadium 2. Berdasarkan data yang diperoleh, pendidikan terakhir terbanyak 
adalah Sekolah Menengah Atas (SMA) yaitu sebanyak $15(44,1 \%)$ orang dan partisipan yang sudah menikah berjumlah $30(88,2 \%)$ orang. Data ini juga menunjukkan bahwa partisipan memiliki tingkat kecemasan hingga mild yaitu sebanyak $7(20,6 \%)$ orang dan $27(79,4 \%)$ lainnya memiliki tingkat kecemasan yang normal. Selain itu, partisipan memiliki tingkat depresi hingga mild yaitu sebanyak $3(8,8 \%)$ orang dan $31(91,2 \%)$ partisipan lainnya memiliki tingkat depresi yang normal.

Berdasarkan usia, partisipan yang mengalami kecemasan dan depresi paling banyak adalah pada rentang usia 38-44 yaitu sebanyak 33,3\% yang mengalami kecemasan dan 16,6\% yang mengalami depresi. Pasien yang berstatus janda memiliki tingkat kecemasan (50\%) dan depresi (50\%) yang lebih tinggi dibandingkan pasien yang belum menikah ataupun pasien yang sudah menikah. Selain itu, Pasien yang didiagnosis kanker payudara selama 1 tahun memiliki tingkat kecemasan $(50 \%)$ dan depresi $(12,5 \%)$ yang lebih tinggi dibandingkan dengan pasien yang baru saja didiagnosis kanker payudara ataupun pasien yang sudah didiagnosis lebih dari 2 tahun.

Berdasarkan data ini juga diketahui bahwa pasien kanker payudara yang sudah stadium 4 memiliki tingkat kecemasan yang paling tinggi yaitu sebesar $50 \%$. Sedangkan tingkat depresi yang paling tinggi adalah pasien yang sudah stadium 2 yaitu sebesar 7,1\%. Seluruh partisipan dalam penelitian ini merupakan orang-orang yang aktif dalam kegiatan keagamaan di lingkungannya. Selain itu, di rumah sakit ini juga seringkali diadakan kunjungan dari yayasan kanker untuk diberikan dukungan dan motivasi bagi pasien-pasien yang ada di rumah sakit tersebut. Beberapa partisipan juga merupakan orang-orang yang terlibat aktif dan menjadi anggota dari yayasan kanker.

Tabel 2. Kategori HADS Partisipan

\begin{tabular}{ccc}
\hline Kategori & Kecemasan & Depresi \\
\hline Normal & $27(79,4 \%)$ & $31(91,2 \%)$ \\
Mild & $7(20,6 \%)$ & $3(8,8 \%)$ \\
Total & $34(100 \%)$ & $34(100 \%)$ \\
\hline
\end{tabular}

Tabel 3. Karakteristik Sosiodemografik Partisipan $(n=34)$

\begin{tabular}{cccccc}
\hline Karakteristik & $\begin{array}{c}\text { Seluruh } \\
\text { Partisipan (\%) }\end{array}$ & Cemas (\%) & Tidak Cemas (\%) & Depresi (\%) & $\begin{array}{c}\text { Tidak Depresi } \\
(\%)\end{array}$ \\
Usia & & & & $5(83,4)$ \\
38-44 & $6(17,6)$ & $2(33,3)$ & $4(66,7)$ & $1(16,6)$ & $8(100)$ \\
$45-51$ & $8(23,5)$ & $2(25,0)$ & $6(75,0)$ & $0(0,0)$ & $9(100)$ \\
$52-58$ & $9(26,5)$ & $3(33,3)$ & $6(66,7)$ & $0(0,0)$ & $10(90,9)$ \\
$59-65$ & $11(32,4)$ & $1(9,1)$ & $10(90,9)$ & $1(9,1)$ & \\
& & & & & \\
Pendidikan & & & & & \\
Terakhir & $5(14,7)$ & $2(40,0)$ & $3(60,0)$ & $1(20,0)$ & $4(80,0)$ \\
SD & $3(8,8)$ & $1(33,3)$ & $2(66,7)$ & $1(33,3)$ & $2(66,7)$ \\
SMP & $15(44,1)$ & $3(20,0)$ & $12(80,0)$ & $0(0,0)$ & $15(100)$ \\
SMA & $4(11,8)$ & $0(0,0)$ & $4(100)$ & $0(0,0)$ & $4(100)$ \\
D3 & $5(14,7)$ & $2(40,0)$ & $3(60,0)$ & $0(0,0)$ & $5(100)$ \\
S1 & $2(5,9)$ & $0(0,0)$ & $2(100)$ & $0(0,0)$ & $2(100)$ \\
S2 & & & & & \\
Status & $30(88,2)$ & $7(23,3)$ & $23(76,7)$ & $1(3,3)$ & $29(96,7)$ \\
Menikah & $2(5,9)$ & $0(0,0)$ & $2(100)$ & $0(0,0)$ & $2(100)$ \\
Tidak Menikah & $2(5,9)$ & $1(50,0)$ & $1(50,0)$ & $1(50,0)$ & $1(50,0)$ \\
Janda & & & & &
\end{tabular}


Awal Diagnosis

(Tahun)

\begin{tabular}{rccccc}
0 & $2(5,9)$ & $0(0,0)$ & $2(100)$ & $0(0,0)$ & $2(100)$ \\
1 & $8(23,5)$ & $4(50,0)$ & $4(50,0)$ & $1(12,5)$ & $7(87,5)$ \\
2 & $8(23,5)$ & $3(37,5)$ & $5(62,5)$ & $0(0,0)$ & $8(100)$ \\
3 & $9(26,5)$ & $0(0,0)$ & $9(100)$ & $1(11,1)$ & $8(88,9)$ \\
4 & $4(11,8)$ & $0(0,0)$ & $4(100)$ & $0(0,0)$ & $4(100)$ \\
5 & $3(8,8)$ & $1(33,3)$ & $2(66,7)$ & $0(0,0)$ & $3(100)$ \\
Stadium & & & & $3(100)$ \\
1 & $3(8,8)$ & $1(33,3)$ & $2(66,7)$ & $0(0,0)$ & $1(7,1)$ \\
2 & $14(41,2)$ & $3(21,4)$ & $11(78,6)$ & $0(0,0)$ & $15(100)$ \\
3 & $15(44,1)$ & $2(13,3)$ & $13(86,7)$ & $0(0,0)$ & $2(100)$ \\
4 & $2(5,9)$ & $1(50,0)$ & $1(50,0)$ & & \\
\hline
\end{tabular}

Berdasarkan uji deskriptif yang dilakukan oleh peneliti, ditemukan bahwa pasien wanita dengan kanker payudara memiliki tingkat kecemasan dan depresi yang normal. Hal ini dikarenakan partisipan yang berpartisipasi dalam penelitian ini sangat aktif dalam kegiatan keagamaan. Selain itu, di rumah sakit $\mathrm{x}$ ini juga seringkali diadakan kunjungan rutin dari yayasan kanker untuk diberikan dukungan dan motivasibagi pasien-pasien yang sedang melakukan pengobatan. Partisipan yang berpartisipasi dalam penelitian ini juga rata-rata sudah menjadi anggota dari yayasan kanker tersebut dan aktif di dalam yayasan kanker tersebut. Hal ini sesuai dengan penelitian yang dilakukan oleh Chong, Mohamed, Sulaiman, dan Zainal (2017) yang menunjukkan hasil score rata-rata kecemasan yaitu 5,1 dan score rata-rata depresi yaitu 3,8, sehingga dapat dikategorikan kedalam kategori normal.

Rendahnya score rata-rata dari kecemasan dan depresi dapat disebabkan oleh faktor-faktor lain yang mempengaruhi bagaimana individu melihat dan mengatasi keadaan yang stresful bagi dirinya. Menurut penelitian yang dilakukan oleh Chong, et al (2017), rendahnya score rata-rata dari kecemasan dan depresi pada penderita kanker dikarenakan adanya peran religiusitas yang mempengaruhi bagaimana seorang individu dapat mengatasi tekanan secara psikologis. Hal ini juga didukung oleh penelitian yang dilakukan oleh Merriam dan Muhamad (2013), menunjukkan bahwa wanita dengan kanker payudara lebih mempercayai kekuatan doa dibandingkan dengan pengobatan secara tradisional untuk menyembuhkan kanker dan menurunkan stress.

Selain faktor religiusitas, berdasarkan penelitian yang dilakukan oleh Liu, et al (2011) menunjukkan bahwa wanita dengan kanker payudara yang mendapatkan lingkungan sosial yang suportif akan lebih mampu untuk menghadapi efek negatif dari keadaan yang menekan seperti, kecemasan dan depresi. Hal ini dikarenakan ketika individu merasakan kecemasan dan depresi, mereka memiliki dukungan sosial dan lingkungan sosial untuk membantu meringankan kecemasan dan depresi yang dialami (Liu, et al., 2011).

Namun, hasil penelitian yang dilakukan oleh Callys-Tagoe, et al (2017) menunjukkan bahwa pasien wanita dengan kanker payudara 84,2\% mengalami depresi dengan prevalensi 39,2\% mild dan $45 \%$ moderate - severe. Sedangkan, prevalensi tingkat kecemasan yaitu $92,5 \%$ dengan prevalensi $34,2 \%$ mild dan 58,3\% moderate- severe. Hal ini didukung oleh penelitian yang dilakukan oleh Giacomo, et al (2016), yang mengatakan bahwa diagnosis kanker payudara memiliki dampak yang negatif terhadap hubungan afeksi, harapan hidup, rencana jangka panjang, produktifitas, dan sosial. Selain itu juga akan berdampak kepada psikologis dari individu, seperti depresi, kecemasan, kemarahan, mood yang buruk, menarik diri dari sosial, isolasi, dan agresifitas (Giacomo, et al., 2016). Hal ini akan memberi dampak yang cukup besar bagi individu, keluarga, lingkungan sosial, dan lingkungan kerja (Giacomo, et al., 2016). 
Kecemasan dan depresi yang dialami oleh wanita dengan kanker payudara akan menyebabkan individu menduga hasil yang buruk, merasa bingung mengenai masa depan, kekhawatiran akan kambuh, dan memiliki permasalahan pada konsekuensi dari penanganan yang diberikan (Aly, Eilateef, \& Mohamed, 2017). Selain itu, diagnosis dan penanganan secara klinis menjadi keadaan yang stressful bagi penderitanya (Srlvastava, et al, 2016). Kecemasan dan depresi pada penderita kanker payudara disebabkan oleh diagnosis kanker, lamanya perawatan, efek samping dari pengobatan, perawatan di rumah sakit yang berulang kali, dan penurunan kualitas hidup (Jadoon, et. al, 2010).

\section{KESIMPULAN DAN SARAN}

Berdasarkan penelitian yang dilakukan terhadap 34 pasien wanita yang didiagnosis kanker payudara dapat disimpulkan bahwa tingkat kecemasan dan depresi yang dimiliki oleh pasien dengan kanker payudara berada dalam kategori normal $(<7)$. Meskipun, beberapa diantara pasien memiliki tingkat kecemasan yang mild dan tidak ditemukan pasien yang terdiagnosis kanker payudara memiliki tingkat kecemasan yang moderate atau severe. Pasien yang memiliki tingkat kecemasan dan depresi yang tinggi adalah pasien yang memiliki rentang usia 38-44 tahun dengan lamanya terdiagnosis adalah 1 tahun. Berdasarkan kesimpulan diatas, peneliti memberikan dapat memberikan saran bagi pihak-pihak yang terkait, yaitu (a) pasien; (b) keluarga pasien; dan (c) tenaga medis.

Pertama, saran yang dapat diberikan bagi pasien adalah penelitian ini dapat menjadi gambaran dan juga informasi bagi pasien wanita dengan kanker payudara mengenai kondisi psikologis yang dialami oleh pasien wanita dengan kanker payudara. Pasien juga disarankan untuk dapat masuk ke dalam lingkungan sosial yang dapat membantu pasien mengatasi kondisi psikologis yang dirasakan. Selain itu, pasien juga dapat mengikuti kegiatan-kegiatan agama yang ada untuk dapat membantu pasien mengatasi keadaan yang stresful bagi pasien.

Kedua, saran yang dapat diberikan kepada keluarga pasien adalah penelitian ini disumsikan dapat menjadi gambaran kondisi psikologis pasien wanita dengan kanker payudara. Keluarga diharapkan untuk dapat memberikan dukungan sosial yang suportif. Hal ini dilakukan agar pasien mampu menghadapi keadaan-keadaaan yang stresful bagi dirinya. Ketiga, bagi tenaga media, Penelitian ini dapat menjadi gambaran dan informasi untuk para praktisi yang bergerak di bidang medis penelitian ini juga dapat bermanfaat bagi para praktisi yang begerak di bidang medis supaya lebih peduli dengan adanya permasalahan psikologis yang dialami oleh pasien yang menderita kanker payudara.

\section{Ucapan Terima Kasih}

Peneliti mengucapkan kepada seluruh partisipan yang terlibat dalam penelitian ini. Selain itu, peneliti juga mengucapkan terimakasih kepada rumah sakit dan yayasan kanker yang ada di Bandung karena telah membantu peneliti dalam penelitian yang dilakukan.

\section{REFERENSI}

American Psychiatric Association. (2013). Diagnostic and Statistical Manual of Mental Disorders (5th Ed.). Arlington, VA: American Psychiatric Association.

Aly, H. Y., Eilateef, A. A. E. A., Mohamed, A. E. S. (2017). Depression and anxiety among females with breast cancer in sohag university: results of an interview study. Remedy Open, 2(1080). pp. 1-7. 
Badger, T., Segrin, C., Dorros, S. M., Meek, P., \& Lopz, A. M. (2007). Depression and anxiety in woman with breast cancer and their partners. Nursing Research, 56(1). pp. 44-63. https://doi.org/10.1002/pon.1111.

Bardwell, W. A., \& Fiorentino, L. (2012). Risk factors for depression in breast cancer. International Journal of Clinical and Health Psychology, 12(2). pp. 311-331.

Baqutayan, S. M. S. (2012). The effect of anxiety on breast cancer patients. Indian Journal of Psychological Medicine, 34(2). pp. 119-125. doi: 10.4103/0253-7176.101774.

Empat penyebab kematian tertinggi di dunia yang sulit ditangani. (2018). CNN Indonesia. Diunduh dari https://www.cnnindonesia.com/gaya-hidup/20180925085456-255-332906/4penyebab-kematian-tertinggi-di-dunia-yang-sulit-ditangani.

Callys-Tagoe, B. N. L., Senaedza, N. A. H., Arthur, C. A., \& Clegg-Lamptey, J. N. (2017). Anxiety and depression among breast cancer patients in a tertiary hospital in ghana. Postgraduate Medical Journal of Ghana, 26(1). pp 54-58.

Compas, B. E., \& Luecken, L. (2002). Psychological adjusment to breast cancer. American Psychological Society, 11(3). pp. 111-114. https://doi.org/10.1111/1467-8721.00180.

Davey, G. (2008). Psychopathology. MA, Malden: British Psychological Society and Blackwell Publishing Ltd.

Giacomo, D. D., Cannita, K..., Ficorella, C. (2016). Breast cancer and psychological resilience among young woman. Journal of Pyschopathology, 22. pp. 191-195.

Jadoon, N. A., Munir, W., Shahzad, M. A., \& Choudhry, Z. S. (2010). Assessment of depression and anxiety in adult cancer outpatients: a cross-sectional study. Biomed Central, 10(594). pp. 1-7. doi: 10.1186/1471-2407-10-594.

Liu, D. G., Wang, S. S., Peng, R. J., Qin, T., ..., \& Yuan, Z. Y. (2011) Interaction of social support and psychological stress on anxiety and depressive symptoms in breast cancer patients. Asian Pacific Journal of Cancer Prevention, 12. pp. 2523-2529.

Merriam, S., \& Muhamad, M. (2013). Roles traditional healers play in cancer treatment in Malaysia: Implications for health promotion and education. Asian Pacific Journal of Cancer Prevention, 14. pp. 3593-3601.

Ng, G. C., Mohamed, S., Sulaiman, A. H., \& Zainal, N. Z. (2017). Anxiety and depression in cancer patients: the association with religiosity and religious coping. Journal od Religion and Health, 56. pp. 575-590. DOI 10.1007/s 10943-016-0267-y.

Shah, R., Rosso, K., \& Nathanson, S. D. (2014). Pathogenesis, prevention, diagnosis and treatment of breast cancer. World Journal of Clinical Oncology, 5(3). DOI: 10.5306/wjco.v5.i3.283.

Srlvastava, V., Ansari, M. A.,... Singh, O. P. (2016). Study of anxiety and depression among breast cancer patient from noth india. Clinical Psychiatry, 2 (1).

Widiyono, S., Setiyarini, S., \& Effendy, C. (2017). Tingkat depresi pada pasien kanker di RSUP Dr. Sardjito, Yogyakarta dan RSUD Prof. Dr. Margono Soekarjo, Purwokerto : pilot study. Indonesian Journal of Cancer, 11(4).

World Health Organization (February, 2018). Cancer burden rises to 18.1 miliion new cases and 9.6 million cancer deaths in 2018. Retrieved from http://www.who.int/cancer/en/.

World Health Organization (February, 2018). Cancer. Retrieved from https://www.who.int/news-room/fact-sheets/detail/cancer.

Zigmond, A. S., \& Snaith, R. P. (1983). The hospital axiety and depression scale. Acta Psychiatr Scand, 57. pp 351-370. 